\title{
Antigen-Presenting Cells in Psoriasis
}

\author{
Dóra Antal $^{1}$, Shahrzad Alimohammadi ${ }^{2} \mathbb{D}$, Péter Bai $^{1}\left(\mathbb{D}\right.$, Attila Gábor Szöllősi ${ }^{2}\left(\mathbb{D}\right.$ and Magdolna Szántó ${ }^{1, *(\mathbb{D})}$ \\ 1 Department of Medical Chemistry, Faculty of Medicine, University of Debrecen, 4032 Debrecen, Hungary; \\ antal.dora@med.unideb.hu (D.A.); baip@med.unideb.hu (P.B.) \\ 2 Department of Immunology, Faculty of Medicine, University of Debrecen, 4032 Debrecen, Hungary; \\ shahrzad.alimohammadi@med.unideb.hu (S.A.); szollosi.attila@med.unideb.hu (A.G.S.) \\ * Correspondence: mszanto@med.unideb.hu
}

check for

updates

Citation: Antal, D.; Alimohammadi,

S.; Bai, P.; Szöllősi, A.G.; Szántó, M.

Antigen-Presenting Cells in Psoriasis. Life 2022, 12, 234. https://doi.org/

$10.3390 /$ life12020234

Academic Editor: Rolland Gyulai

Received: 3 January 2022

Accepted: 31 January 2022

Published: 3 February 2022

Publisher's Note: MDPI stays neutral with regard to jurisdictional claims in published maps and institutional affiliations.

Copyright: (c) 2022 by the authors. Licensee MDPI, Basel, Switzerland. This article is an open access article distributed under the terms and conditions of the Creative Commons Attribution (CC BY) license (https:// creativecommons.org/licenses/by/ $4.0 /)$.

\begin{abstract}
Psoriasis is classically considered a chronic inflammatory skin disorder, however the identification of autoantigens in its pathogenesis established it as a $\mathrm{T}$ cell mediated autoimmune disease. As such professional antigen-presenting cells (APCs) are key players in the development of lesions. APCs in the skin include dendritic cells, Langerhans cells and monocytes/macrophages. In addition, epidermal keratinocytes and dermal mast cells are also endowed with antigen-presenting capacity. Skin APCs have central role in the maintenance of cutaneous immune homeostasis, as well as in initiating and sustaining inflammation under pathologic conditions. In this review we discuss the functional specialization of human skin APCs that promote T cell activation and adaptive immune response during psoriasis initiation and onset.
\end{abstract}

Keywords: psoriasis; antigen-presenting cells; autoantigens; keratinocyte; mast cell; neuropeptide

\section{Introduction}

Psoriasis is a chronic, relapsing-remitting skin disorder that affects about $2 \%$ of the world's population. The clinical phenotype of the most common plaque-type psoriasis presents well-demarcated, scaly, inflamed patches, typically on knees, elbows, or scalp [1]. The etiology of psoriasis is complex, with environmental and genetic factors contributing to disease development. Psoriasis is considered a mixed auto-inflammatory and autoimmune skin disease with the involvement of both innate and adaptive arms of the immune system in its pathogenesis [2]. In addition, the nervous system contributes to disease development and maintenance through the release of neuropeptides that may modify the function of immune cells in the skin [3].

There are multiple genetic risk variants that has been associated with psoriasis. Among them, the first identified was HLA-C*06:02 [4], which still remains the most strongly associated psoriasis susceptibility allele $[5,6]$. HLA-C*06:02 encoded protein belongs to the major histocompatibility complex (MHC) class I molecules and plays an important role in presenting cytoplasmic antigens to $\mathrm{CD} 4^{+}$and $\mathrm{CD} 8^{+} \mathrm{T}$ cells [7]. In addition, other genes involved in antigen presentation were identified as psoriasis genetic risk factors, such as the ERAP1 and ERAP2, which encode amino-peptidase enzymes that can cleave peptide antigens before presentation to T cells [8]. T cells, and specifically $\mathrm{CD} 8^{+} \mathrm{T}$ cells have been recognized as the critical players in psoriasis pathogenesis $[9,10]$. CD8 ${ }^{+} \mathrm{T}$ cells are abundant in psoriasis lesions forming multiple clones [11], suggesting that these cells respond to a set of locally presented antigens. To date, four psoriasis-associated autoantigens have been described: self-nucleic acid complexes of the cathelicidin antimicrobial peptide (LL37 or CAMP) [12], the melanocytic antigen ADAMTS-like protein 5 (ADAMTSL5) [13], the lipid antigen PLA2G4D [14] and keratin 17 [15], which may trigger autoimmune responses in psoriasis. LL37, ADAMTSL5 and keratin 17 may be presented by HLA-C molecules, while CD1a ${ }^{+}$Langerhans cells may present PLA2G4D to the T cell receptors (TCR) of reactive $\mathrm{CD}^{+}{ }^{+}$or $\mathrm{CD} 8^{+} \mathrm{T}$ cells $[16,17]$. As a consequence, activated $\mathrm{T}$ cells release proinflammatory cytokines, including interleukin (IL)17A, tumor necrosis factor (TNF) $\alpha$, 
interferon (IFN) $\gamma$ and IL22 $[9,18]$ that act on keratinocytes, which sustain and propagate the chronic inflammatory process by producing pro-inflammatory cytokines, chemokines, and antimicrobial peptides, driving the psoriatic inflammatory circuit. The above findings well illustrate that antigen presentation plays a key role in psoriasis pathomechanism. Professional antigen-presenting cells (APCs) in the skin involve different dendritic cell (DC) subsets, Langerhans cells and macrophages [19]. In addition, epidermal keratinocytes and mast cells are also capable to antigen presentation by expressing MHC class I [20], and under certain conditions even MHC class II [21-23] molecules. This concise review will consider only human data regarding the functional role of APCs in psoriasis.

\section{Professional and "Non-Professional" Antigen-Presenting Cells in the Psoriasis Pathomechanism}

\subsection{Professional APCs}

\subsubsection{Plasmacytoid Dendritic Cells}

Plasmacytoid dendritic cells (pDCs) represent a specialized, type I IFN-producing DC subset that have a major role in antiviral response [24]. pDCs display a unique toll-like receptor (TLR) profile by expressing TLR7 and TLR9 [25], by which pDCs recognize viral and microbial nucleic acid motifs [26]. Under normal conditions, pDCs circulate in peripheral blood and are present in lymphoid tissues [27,28], but not in healthy skin [29]. However, in case of infection, injury or autoimmunity, pDCs can infiltrate the dermis and the basal layer of the epidermis $[29,30]$. pDCs were detected both in lesional and uninvolved skin of psoriatic patients, and pDC-derived IFN $\alpha$ was shown to be essential for the early developmental stage of psoriasis by promoting the maturation of myeloid DCs, and inducing $\mathrm{T}$ cell expansion in pre-psoriatic skin [30]. In contrast to myeloid DCs, blood pDCs of psoriasis patients are dormant, and function only in the psoriatic skin milieu [31]. Interestingly, pDCs are absent in atopic dermatitis lesions, suggesting a unique role for pDCs in psoriasis pathogenesis $[29,30,32]$. In classical psoriasis, pDC-derived IFN $\alpha$ activates myeloid DCs to produce TNF and IL23. TNF, in turn, induces maturation of pDCs, which limit their IFN $\alpha$ secretion [33]. In the absence of TNF, maturation of pDCs decreases, and their IFN $\alpha$ production is extended, driving a phenomenon called paradoxical psoriasis [33,34], which was introduced as a side effect of anti-TNF therapy. Psoriasis may also be exacerbated in patients under treatment with imiquimod that is a strong inducer of TLR7 in pDCs [32]. The molecular players of $\mathrm{pDC}$ activation in psoriasis was getting characterized over the past decade. Dermal expression of the chemotactic factor chemerin may be an early event leading to $\mathrm{pDC}$ recruitment to the developing psoriatic skin [35]. During later stages, in chronic plaques, chemerin expression is markedly lower, which coincides with the reduced number of pDCs [35]. Under normal conditions, host-derived self-nucleic acids released by apoptotic or necrotic cells cannot activate pDCs. However, in the presence of antimicrobial peptides (AMP), such as LL37 (or CAMP), B-defensins and Ribonuclease 7, inert self-DNA can be converted into potent autoantigen triggering IFN $\alpha$ production by $\mathrm{pDCs}$, and driving autoimmunity in psoriasis [12,36-38]. Of note, AMPs are overexpressed in psoriasis and, consequently, pDC activation is sustained [37]. Post-translational modifications also seem to influence IFN $\alpha$ production by pDCs. The palmitoylating agent Zdhhc2 is required for pDC accumulation in psoriatic skin by controlling the phosphorylation of IRF7 that is a key transcription factor regulating IFN $\alpha$ production of $\mathrm{pDCs}$ [39]. The $\mathrm{H} 4$ histamine receptor is highly expressed on pDCs in psoriasis and histamine regulates the cytokine production and migration of pDCs [40], supporting the role of neuroimmune interactions in psoriasis progression.

\subsubsection{Dermal Myeloid Dendritic Cells}

The majority of resident DCs in the skin are of myeloid origin and are located in the dermis [41]. In steady-state healthy skin, the majority of dermal myeloid DCs express CD1c, also known as blood DC antigen (BDCA) 1, and CD11c, which are useful markers to distinguish dermal DCs from macrophages [42]. In psoriasis, however, $\mathrm{CD} 11 \mathrm{c}^{+} \mathrm{CD} 1 \mathrm{c}^{-}$ 
"inflammatory" dermal DCs dominate [43]. In the psoriatic skin, dermal DCs are activated by IFN $\alpha$ released by $\mathrm{pDC}$, by LL37-self-DNA/RNA autoantigens through TLR8 expression, as well as by keratinocyte-derived pro-inflammatory cytokines such as TNF, IL6, and IL1 $\beta$ [44,45]. Inflammatory DCs may produce TNF, inducible nitric oxide synthase (iNOS), IL12, IL20, and they are the major sources of IL23 in psoriatic lesions [43]. IL20 promotes proliferation of keratinocytes [46], IL23 induces terminal differentiation and IL17 production of $\mathrm{CD}^{+} \mathrm{T}$ helper (Th) 17 and CD8 ${ }^{+} \mathrm{T}$ cells [47], and IL12 may polarize CD4 ${ }^{+} \mathrm{Th} 1$ cells [42]. Pro-inflammatory Th17 and Th1 cytokines then act on keratinocytes, propagating chronic inflammation. In addition, LL37 and ADAMTSL5 antigens are coexpressed with DCs in lesional skin, suggesting that DCs are involved in the presentation of these antigens to auto-reactive $\mathrm{T}$ cell populations [48].

\subsubsection{Langerhans Cells}

Langerhans cells, first described by Paul Langerhans in 1868 and mistakenly identified as members of the peripheral nervous system, have since been accepted as dendritic cells located in the epidermis [49], which makes them the only professional APC in the steady-state in the human epidermis. Interestingly, although originally considered a typical example of migratory dendritic cells, the exact classification of these cells as resident macrophages (based on their ontogeny) or dendritic cells (based on their function) is still not settled [50].

Their role in psoriasis is also debated, as certain publications have reported decreased [51-53], increased [54-56], and even unchanged numbers of LCs in psoriatic lesions [57-60]. The differences in results stem from a variety of factors, and might be due to the fact that psoriasis is not a completely homogenous disease. By differentiating between early and late-onset psoriasis we are already faced with a marked difference in the role of Langerhans cells in the disease: in early onset psoriasis (generally regarded as starting before 40) the mobilization and migration of LCs from the epidermis severely impaired [61,62], while in late-onset psoriasis keratinocytes do not produce cytokines that inhibit the migration of LCs [63].

Pro-inflammatory roles of LCs in psoriasis pathogenesis were found at the molecular level, where there is a possibility for a positive feedback loop to develop between keratinocytes, LCs and T cells. LCs produce IL23 after STAT3 activation in keratinocytes via the p38 $\alpha$ signalling pathway [60,64,65]. IL23 produced by LCs stimulates IL17 release from T cells, which leads to changes in keratinocyte secretome resulting in retention of LCs in the epidermis and further IL17 release. The fact that LCs are retained might also promote the development of the disease since migratory LCs can induce tolerogenic responses in draining lymph nodes. Since psoriasis is at least in part an autoimmune disease, this loss of local tolerance could be one of the major contributors to the disease.

Of note, it is not only peptide antigens that can contribute to psoriasis development, but self-lipid antigens as well. One of the primary markers used to distinguish LCs in situ is CD1a, which has been shown to present self-lipid antigens to $\mathrm{CD}^{+} \mathrm{T}$ helper $\left(\mathrm{T}_{\mathrm{H}}\right)$ cells, especially in psoriatic skin [16]. LCs are under neuropeptide control in the epidermis, as both calcitonin gene-related peptide (CGRP) and vasoactive intestinal peptide (VIP) may suppress antigen presentation by LCs [66].

\subsubsection{Macrophages}

Macrophages are important effectors of the innate immune system. Primarily, macrophages are phagocytic cells vital to host survival, as macrophages are involved in the clearance of erythrocytes, cellular debris generated during tissue remodelling, as well as apoptotic and necrotic cells [67]. Macrophages specifically express the scavenger receptor CD163 and Factor XIIIA (FXIIIA) in normal skin which distinguish macrophages from resident dermal DCs $[68,69]$. The immune-stimulatory capacity of $\mathrm{CD}_{163}{ }^{+} \mathrm{FXIIIA}^{+}$macrophages is markedly lower than that of dermal DCs [69]. Macrophages are more abundant in psoriatic lesions compared to normal skin as determined by increased expression of CD163 [68], 
but the exact role of macrophages in psoriasis is not fully understood. LL37 promotes proinflammatory macrophage differentiation $[70]$ and $\mathrm{CD} 163^{+}$macrophages are co-expressed with LL37 and ADAMTSL5 in both lesional and non-lesional psoriatic skin [48], implying that macrophages, similarly as DCs, take part in the presentation of autoantigens to T cells. Like myeloid DCs, macrophages also have the ability to produce IL23 that may promote activation of $\mathrm{CD}^{+}$and $\mathrm{CD} 8^{+} \mathrm{T}$ cell populations and contribute to the IL17-mediated inflammatory response is psoriatic skin [71].

A recent article shed some new light on macrophages in psoriasis by revealing a re-emergence of developmental macrophage gene programs in psoriasis [72]. Single-cell RNA-sequencing analyses have been performed from developing healthy fetal skin, adult healthy skin and adult skin with psoriasis. Macrophages of adult skin were classified into Mac1 and Mac2 subtypes based on specific marker signatures [72,73]. Both Mac1 and Mac2 express CD68, while Mac1 is characterized by higher expression of CD163, macrophage receptor with collagenous structure (MARCO), and complement transcripts. Mac2, on the other hand, displays expression of FXIIIA and markers of alternative activation and immune suppression. Adult skin Mac2, which aligned with fetal skin macrophages, was significantly elevated in psoriatic skin, suggesting a role for Mac2 in psoriasis pathogenesis and also a shared cellular program with macrophages of fetal development [72].

\subsection{Non-Professional APCs in Psoriasis}

\subsubsection{Keratinocytes}

Though the pathogenic role of keratinocytes in psoriasis was long debated, growing evidence suggests that hyperproliferation and aberrant differentiation of keratinocytes is a consequence rather than the cause of immune activation in psoriasis, and keratinocytes play a central role in linking innate and adaptive immune responses during disease manifestation [74]. Keratinocytes facilitate the initiation phase of psoriasis by expressing the chemotactic factor chemerin that promotes pDC migration to pre-psoriatic skin [35]. Certain triggering factors, such as epidermal injury may promote keratinocytes to excessively produce AMPs that have the ability to form complex with otherwise inert self-DNA and thereby act as strong inducers of $\mathrm{pDC}$ activation and secretion of IFN $\alpha$ in psoriatic skin [38]. In addition, the cathelicidin AMP LL37 can induce components of innate immunity in keratinocytes by a paracrine or autocrine manner. Among them, the IL1 family member IL36 $\gamma$ is highly expressed in psoriatic skin and increases the production of CXCL8, CXCL1, CXCL10 and CCL20 chemokines, as well as cytokines IL6, G-CSF, and GM-CSF in keratinocytes [75]. These chemoattractants can recruit and activate a burst of immune cells, such as mDCs, macrophages, neutrophils, T cells, and Natural Killer cells in the early stage of psoriasis [75]. IL36 $\gamma$ may also lead to proliferative responses in keratinocytes [44]. Furthermore, keratinocytes are the main cell type in psoriasis that express IL17R, the receptor for IL17 [74], and the keratinocyte IL17 gene set is enriched in the psoriasis transcriptome [76]. IL17 induce proliferation and further AMP (e.g., defensins, cathelicidins) and pro-inflammatory cytokine (e.g., IL6, IL8, TNF) production in keratinocytes, and these products act back on DCs and T cells, creating a self-amplifying loop [77]. Moreover, keratinocyte-produced IL23 is, in itself, sufficient to induce IL17 production of T cells and cause chronic skin inflammation [78]. Keratinocytes are important sources of angiogenic factors and the autoantigen keratin 17, as well [79]. Keratinocytes may be involved in the presentation of soluble antigens to $\mathrm{CD} 8^{+} \mathrm{T}$ cells through HLA-C molecules (Liang, 2017), which may be a central driver of inflammatory circuits in plaque psoriasis. Keratinocytes are targeted by neuropeptides in psoriatic lesions. Serotonin stimulates keratinocyte proliferation and differentiation through the 5-HT3 that is located in the basal layer of the epidermis in lesional skin of psoriasis [80]. SP can also induce proliferation and pro-inflammatory cytokine (e.g., IL1, IL8, TNF $\alpha$ ) synthesis in keratinocytes [81]. 


\subsubsection{Mast Cells}

Mast cells (MCs) are tissue-resident effectors of innate immune responses that have a well-defined role in allergic responses. In the skin, MCs are found in the upper dermis, in close vicinity to DCs [82]. A role for MCs in psoriasis has long been postulated [83], but consecutive studies are still missing. MCs can be activated by neuropeptides [84]. SP induces vascular endothelial growth factor (VEGF) release from MCs that is increased in psoriasis [85]. MCs were found as important contributors to IL17 production in psoriatic lesions [86]. IFN $\gamma$-primed human mast cells can induce the generation of IL22-producing $\mathrm{T}_{\mathrm{H}}$ cells from $\mathrm{CD}^{+}$memory $\mathrm{T}$ cells, and this process was demonstrated in psoriasis [87]. A recent immune cell infiltrate analysis of psoriatic lesional skin revealed that receptor tyrosine kinase (c-Kit) and tryptase double-positive, activated MCs are enriched in psoriatic skin, and their number gradually decreases upon clinical treatment, supporting an important role of MC activation in the progression of psoriasis [88].

MCs express MHC class II [23,89] and can act as non-professional APCs [90]. Baseline or IFN $\gamma$-primed MCs can take up both soluble and particulate antigens and present them to autologous $\mathrm{CD}^{+} \mathrm{T}$ cells [90]. Whether antigen presentation by MCs is significant in the pathomechanism of psoriasis remains to be elucidated. It is of note though, that LL37, which may act as an autoantigen in psoriasis, can directly induce pro-inflammatory cytokine synthesis in MCs [91].

\section{Summary and Future Perspectives}

Our perception of APCs in pathological skin conditions has greatly improved in the past decade, owing, in part, to a more accurate definition of surface markers of different APC subsets under steady-state and inflammatory milieu. In parallel, appreciation of the central role of APCs and autoimmune processes in the pathomechanism of psoriasis is constantly growing (Figure 1). Naturally, development of psoriasis cannot simply be explained by autoantigen presentation in predisposed individuals. The fine-tuning of the complex interplay between the innate and adaptive arms of the immune system determines the actual clinical manifestation of psoriasis. Data supports that innate mechanisms are more dominant in patients with severe outcome and systemic comorbidities, while in mild disease mechanisms of adaptive immunity are more important [92]. A better understanding of the functional programming of the APC network in the psoriatic microenvironment in different disease stages and manifestations may be vital in the development of novel therapeutic targets. This is of importance not only in the case of psoriasis, but in other inflammatory and autoimmune diseases that share similar pathogenetic pathways. 


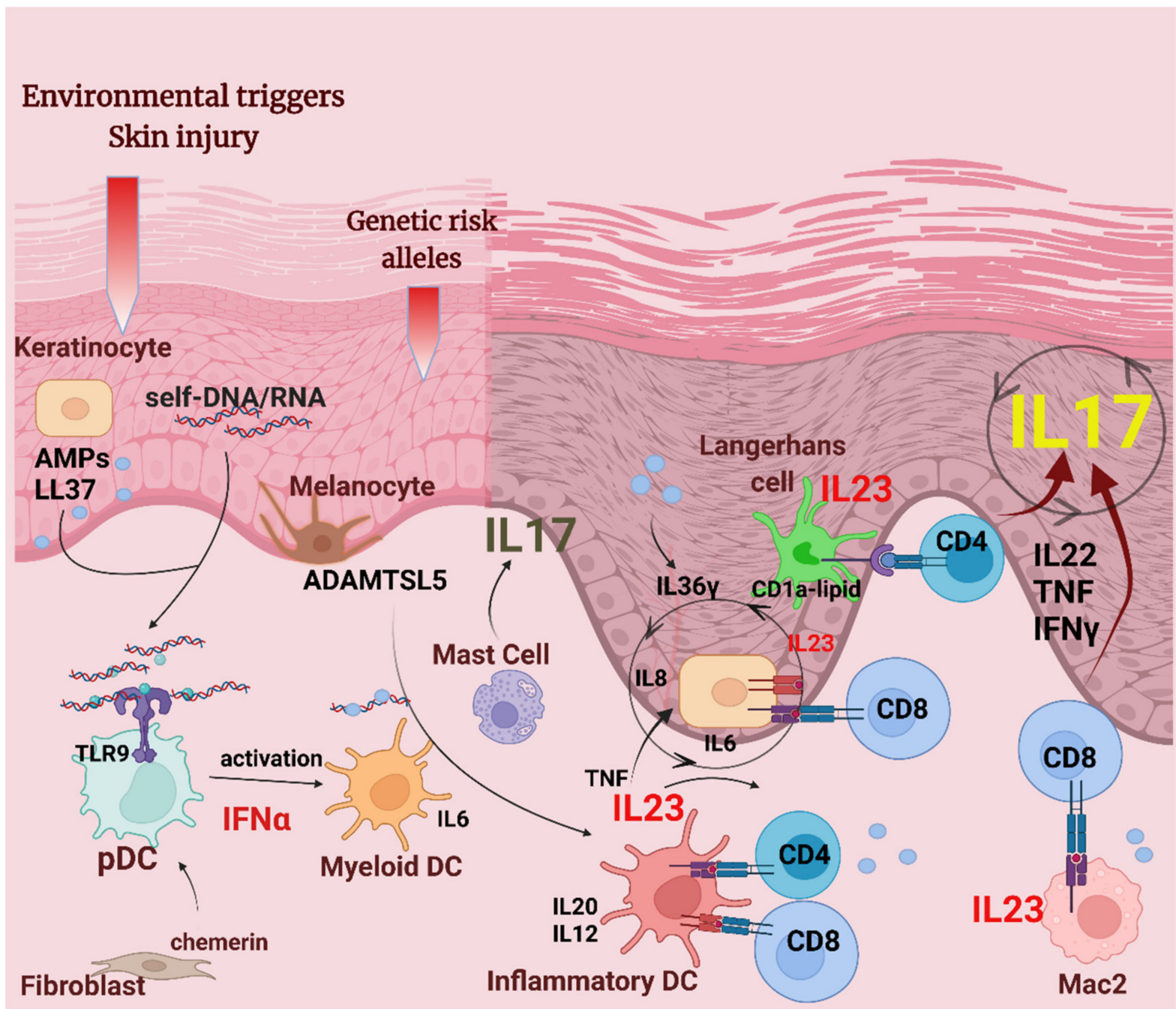

Figure 1. APCs in psoriasis pathogenesis. Environmental factors, such as epidermal injury, together with psoriasis susceptibility genes, are involved in the pathogenic mechanisms leading to psoriasis initiation. In the initiation phase, damaged keratinocytes release self-nucleic acids and AMPs, such as LL37. LL37/self-nucleic acid complexes and the chemotactic factor chemerin recruit plasmacytoid dendritic cells (pDCs) that release IFN $\alpha$, leading to the activation of dermal myeloid DCs and inflammatory dermal DCs that produce cytokines IL20, IL12, and IL23. Autoantigens LL37 and ADAMTSL5 may be presented on HLA-C (MHC class I) by DCs, keratinocytes, and macrophages to $\mathrm{CD}^{+}$and $\mathrm{CD}^{+} \mathrm{T}$ cells. Activated T cells will produce pro-inflammatory cytokines IL22, TNF, IFN $\gamma$, and IL17 that act on keratinocytes to induce the proliferation and production of AMPs and keratinocyte-derived pro-inflammatory cytokines. IL23 secreted by keratinocytes give feedback on $\mathrm{T}$ cells and drive a sustained, chronic skin inflammation. Activated mast cells have a share in IL17 production in psoriatic plaques. Macrophages and Langerhans cells also contribute to the psoriatic milieu by presenting cytosolic antigens to reactive T cells, and producing IL23.

Author Contributions: Writing-original draft preparation: D.A., S.A., A.G.S., M.S.; writingreview and editing: A.G.S., P.B., M.S. All authors have read and agreed to the published version of the manuscript.

Funding: Our work was supported by the National Research, Development and Innovation Office of Hungary (FK134588, K123975, and FK134993), the University of Debrecen, and the Thematic Excellence Program (TKP2021-EGA-19 and TKP2021-EGA-20) of the Ministry for Innovation and Technology in Hungary.

Conflicts of Interest: The authors declare no conflict of interest. 


\section{References}

1. Boehncke, W.H.; Schon, M.P. Psoriasis. Lancet 2015, 386, 983-994. [CrossRef]

2. Liang, Y.; Sarkar, M.K.; Tsoi, L.C.; Gudjonsson, J.E. Psoriasis: A mixed autoimmune and autoinflammatory disease. Curr. Opin. Immunol. 2017, 49, 1-8. [CrossRef] [PubMed]

3. Raychaudhuri, S.P.; Farber, E.M. Neuroimmunologic aspects of psoriasis. Cutis 2000, 66, 357-362.

4. Tiilikainen, A.; Lassus, A.; Karvonen, J.; Vartiainen, P.; Julin, M. Psoriasis and HLA-Cw6. Br. J. Dermatol. 1980, 102, 179-184. [CrossRef] [PubMed]

5. Chen, L.; Tsai, T.F. HLA-Cw6 and psoriasis. Br. J. Dermatol. 2018, 178, 854-862. [CrossRef]

6. Nair, R.P.; Stuart, P.E.; Nistor, I.; Hiremagalore, R.; Chia, N.V.C.; Jenisch, S.; Weichenthal, M.; Abecasis, G.R.; Lim, H.W.; Christophers, E.; et al. Sequence and haplotype analysis supports HLA-C as the psoriasis susceptibility 1 gene. Am. J. Hum. Genet. 2006, 78, 827-851. [CrossRef]

7. Gudjonsson, J.E.; Johnston, A.; Sigmundsdottir, H.; Valdimarsson, H. Immunopathogenic mechanisms in psoriasis. Clin. Exp. Immunol. 2004, 135, 1-8. [CrossRef]

8. Genetic Analysis of Psoriasis Consortium; The Wellcome Trust Case Control Consortium; Strange, A.; Capon, F.; Spencer, C.C.; Knight, J.; Weale, M.E.; Allen, M.H.; Barton, A.; Band, G.; et al. A genome-wide association study identifies new psoriasis susceptibility loci and an interaction between HLA-C and ERAP1. Nat. Genet. 2010, 42, 985-990. [CrossRef]

9. Di Meglio, P.; Villanova, F.; Navarini, A.A.; Mylonas, A.; Tosi, I.; Nestle, F.O.; Conrad, C. Targeting CD8(+) T cells prevents psoriasis development. J. Allergy Clin. Immunol. 2016, 138, 274-276. [CrossRef]

10. Schon, M.P. Adaptive and Innate Immunity in Psoriasis and Other Inflammatory Disorders. Front. Immunol. 2019, 10, 1764. [CrossRef]

11. Lin, W.J.; Norris, D.A.; Achziger, M.; Kotzin, B.L.; Tomkinson, B. Oligoclonal expansion of intraepidermal T cells in psoriasis skin lesions. J. Investig. Dermatol. 2001, 117, 1546-1553. [CrossRef] [PubMed]

12. Lande, R.; Botti, E.; Jandus, C.; Dojcinovic, D.; Fanelli, G.; Conrad, C.; Chamilos, G.; Feldmeyer, L.; Marinari, B.; Chon, S.; et al. The antimicrobial peptide LL37 is a T-cell autoantigen in psoriasis. Nat. Commun. 2014, 5, 5621. [CrossRef] [PubMed]

13. Arakawa, A.; Siewert, K.; Stohr, J.; Besgen, P.; Kim, S.M.; Ruhl, G.; Nickel, J.; Vollmer, S.; Thomas, P.; Krebs, S.; et al. Melanocyte antigen triggers autoimmunity in human psoriasis. J. Exp. Med. 2015, 212, 2203-2212. [CrossRef] [PubMed]

14. Cheung, K.L.; Jarrett, R.; Subramaniam, S.; Salimi, M.; Gutowska-Owsiak, D.; Chen, Y.L.; Hardman, C.; Xue, L.; Cerundolo, V.; $\mathrm{Ogg}$, G. Psoriatic T cells recognize neolipid antigens generated by mast cell phospholipase delivered by exosomes and presented by CD1a. J. Exp. Med. 2016, 213, 2399-2412. [CrossRef] [PubMed]

15. Yunusbaeva, M.; Valiev, R.; Bilalov, F.; Sultanova, Z.; Sharipova, L.; Yunusbayev, B. Psoriasis patients demonstrate HLA-Cw*06:02 allele dosage-dependent $\mathrm{T}$ cell proliferation when treated with hair follicle-derived keratin 17 protein. Sci. Rep. 2018, 8, 6098. [CrossRef]

16. Kim, J.H.; Hu, Y.; Yongqing, T.; Kim, J.; Hughes, V.A.; Le Nours, J.; Marquez, E.A.; Purcell, A.W.; Wan, Q.; Sugita, M.; et al. CD1a on Langerhans cells controls inflammatory skin disease. Nat. Immunol. 2016, 17, 1159-1166. [CrossRef]

17. Ten Bergen, L.L.; Petrovic, A.; Aarebrot, A.K.; Appel, S. Current knowledge on autoantigens and autoantibodies in psoriasis. Scand. J. Immunol. 2020, 92, e12945. [CrossRef]

18. Kryczek, I.; Bruce, A.T.; Gudjonsson, J.E.; Johnston, A.; Aphale, A.; Vatan, L.; Szeliga, W.; Wang, Y.; Liu, Y.; Welling, T.H.; et al. Induction of IL-17+ T cell trafficking and development by IFN-gamma: Mechanism and pathological relevance in psoriasis. J. Immunol. 2008, 181, 4733-4741. [CrossRef]

19. Kashem, S.W.; Haniffa, M.; Kaplan, D.H. Antigen-Presenting Cells in the Skin. Annu. Rev. Immunol. 2017, 35, 469-499. [CrossRef]

20. Black, A.P.; Ardern-Jones, M.R.; Kasprowicz, V.; Bowness, P.; Jones, L.; Bailey, A.S.; Ogg, G.S. Human keratinocyte induction of rapid effector function in antigen-specific memory CD4+ and CD8+ T cells. Eur. J. Immunol. 2007, 37, 1485-1493. [CrossRef]

21. Czernielewski, J.M.; Bagot, M. Class II MHC antigen expression by human keratinocytes results from lympho-epidermal interactions and gamma-interferon production. Clin. Exp. Immunol. 1986, 66, 295-302. [PubMed]

22. Gottlieb, A.B.; Lifshitz, B.; Fu, S.M.; Staiano-Coico, L.; Wang, C.Y.; Carter, D.M. Expression of HLA-DR molecules by keratinocytes, and presence of Langerhans cells in the dermal infiltrate of active psoriatic plaques. J. Exp. Med. 1986, 164, 1013-1028. [CrossRef] [PubMed]

23. Kambayashi, T.; Allenspach, E.J.; Chang, J.T.; Zou, T.; Shoag, J.E.; Reiner, S.L.; Caton, A.J.; Koretzky, G.A. Inducible MHC class II expression by mast cells supports effector and regulatory T cell activation. J. Immunol. 2009, 182, 4686-4695. [CrossRef] [PubMed]

24. Cella, M.; Jarrossay, D.; Facchetti, F.; Alebardi, O.; Nakajima, H.; Lanzavecchia, A.; Colonna, M. Plasmacytoid monocytes migrate to inflamed lymph nodes and produce large amounts of type I interferon. Nat. Med. 1999, 5, 919-923. [CrossRef] [PubMed]

25. Krug, A.; Towarowski, A.; Britsch, S.; Rothenfusser, S.; Hornung, V.; Bals, R.; Giese, T.; Engelmann, H.; Endres, S.; Krieg, A.M.; et al. Toll-like receptor expression reveals CpG DNA as a unique microbial stimulus for plasmacytoid dendritic cells which synergizes with CD40 ligand to induce high amounts of IL-12. Eur. J. Immunol. 2001, 31, 3026-3037. [CrossRef]

26. Gilliet, M.; Cao, W.; Liu, Y.J. Plasmacytoid dendritic cells: Sensing nucleic acids in viral infection and autoimmune diseases. Nat. Rev. Immunol. 2008, 8, 594-606. [CrossRef]

27. Siegal, F.P.; Kadowaki, N.; Shodell, M.; Fitzgerald-Bocarsly, P.A.; Shah, K.; Ho, S.; Antonenko, S.; Liu, Y.J. The nature of the principal type 1 interferon-producing cells in human blood. Science 1999, 284, 1835-1837. [CrossRef] 
28. Velasquez-Lopera, M.M.; Correa, L.A.; Garcia, L.F. Human spleen contains different subsets of dendritic cells and regulatory T lymphocytes. Clin. Exp. Immunol. 2008, 154, 107-114. [CrossRef]

29. Wollenberg, A.; Wagner, M.; Gunther, S.; Towarowski, A.; Tuma, E.; Moderer, M.; Rothenfusser, S.; Wetzel, S.; Endres, S.; Hartmann, G. Plasmacytoid dendritic cells: A new cutaneous dendritic cell subset with distinct role in inflammatory skin diseases. J. Investig. Dermatol. 2002, 119, 1096-1102. [CrossRef]

30. Nestle, F.O.; Conrad, C.; Tun-Kyi, A.; Homey, B.; Gombert, M.; Boyman, O.; Burg, G.; Liu, Y.J.; Gilliet, M. Plasmacytoid predendritic cells initiate psoriasis through interferon-alpha production. J. Exp. Med. 2005, 202, 135-143. [CrossRef]

31. Khasawneh, A.; Barath, S.; Medgyesi, B.; Beke, G.; Dajnoki, Z.; Gaspar, K.; Jenei, A.; Pogacsas, L.; Pazmandi, K.; Gaal, J.; et al. Myeloid but not plasmacytoid blood DCs possess Th1 polarizing and Th1/Th17 recruiting capacity in psoriasis. Immunol. Lett. 2017, 189, 109-113. [CrossRef] [PubMed]

32. Gilliet, M.; Conrad, C.; Geiges, M.; Cozzio, A.; Thurlimann, W.; Burg, G.; Nestle, F.O.; Dummer, R. Psoriasis triggered by toll-like receptor 7 agonist imiquimod in the presence of dermal plasmacytoid dendritic cell precursors. Arch. Dermatol. 2004, 140, 1490-1495. [CrossRef] [PubMed]

33. Conrad, C.; Di Domizio, J.; Mylonas, A.; Belkhodja, C.; Demaria, O.; Navarini, A.A.; Lapointe, A.K.; French, L.E.; Vernez, M.; Gilliet, M. TNF blockade induces a dysregulated type I interferon response without autoimmunity in paradoxical psoriasis. Nat. Commun. 2018, 9, 25. [CrossRef] [PubMed]

34. Mylonas, A.; Conrad, C. Psoriasis: Classical vs. Paradoxical. The Yin-Yang of TNF and Type I Interferon. Front. Immunol. 2018, 9 , 2746. [CrossRef] [PubMed]

35. Albanesi, C.; Scarponi, C.; Pallotta, S.; Daniele, R.; Bosisio, D.; Madonna, S.; Fortugno, P.; Gonzalvo-Feo, S.; Franssen, J.D.; Parmentier, M.; et al. Chemerin expression marks early psoriatic skin lesions and correlates with plasmacytoid dendritic cell recruitment. J. Exp. Med. 2009, 206, 249-258. [CrossRef]

36. Kopfnagel, V.; Wagenknecht, S.; Harder, J.; Hofmann, K.; Kleine, M.; Buch, A.; Sodeik, B.; Werfel, T. RNase 7 Strongly Promotes TLR9-Mediated DNA Sensing by Human Plasmacytoid Dendritic Cells. J. Investig. Dermatol. 2018, 138, 872-881. [CrossRef]

37. Lande, R.; Chamilos, G.; Ganguly, D.; Demaria, O.; Frasca, L.; Durr, S.; Conrad, C.; Schroder, J.; Gilliet, M. Cationic antimicrobial peptides in psoriatic skin cooperate to break innate tolerance to self-DNA. Eur. J. Immunol. 2015, 45, 203-213. [CrossRef]

38. Lande, R.; Gregorio, J.; Facchinetti, V.; Chatterjee, B.; Wang, Y.H.; Homey, B.; Cao, W.; Wang, Y.H.; Su, B.; Nestle, F.O.; et al. Plasmacytoid dendritic cells sense self-DNA coupled with antimicrobial peptide. Nature 2007, 449, 564-569. [CrossRef]

39. Zhou, B.; Yang, W.; Li, W.; He, L.; Lu, L.; Zhang, L.; Liu, Z.; Wang, Y.; Chao, T.; Huang, R.; et al. Zdhhc2 Is Essential for Plasmacytoid Dendritic Cells Mediated Inflammatory Response in Psoriasis. Front. Immunol. 2020, 11, 607442. [CrossRef]

40. Gschwandtner, M.; Mommert, S.; Kother, B.; Werfel, T.; Gutzmer, R. The histamine H4 receptor is highly expressed on plasmacytoid dendritic cells in psoriasis and histamine regulates their cytokine production and migration. J. Investig. Dermatol. 2011, 131, 1668-1676. [CrossRef]

41. Nestle, F.O.; Zheng, X.G.; Thompson, C.B.; Turka, L.A.; Nickoloff, B.J. Characterization of dermal dendritic cells obtained from normal human skin reveals phenotypic and functionally distinctive subsets. J. Immunol. 1993, 151, 6535-6545. [PubMed]

42. Zaba, L.C.; Fuentes-Duculan, J.; Eungdamrong, N.J.; Abello, M.V.; Novitskaya, I.; Pierson, K.C.; Gonzalez, J.; Krueger, J.G.; Lowes, M.A. Psoriasis is characterized by accumulation of immunostimulatory and Th1/Th17 cell-polarizing myeloid dendritic cells. J. Investig. Dermatol. 2009, 129, 79-88. [CrossRef] [PubMed]

43. Zaba, L.C.; Krueger, J.G.; Lowes, M.A. Resident and “inflammatory" dendritic cells in human skin. J. Investig. Dermatol. 2009, 129, 302-308. [CrossRef] [PubMed]

44. Lowes, M.A.; Suarez-Farinas, M.; Krueger, J.G. Immunology of psoriasis. Annu. Rev. Immunol. 2014, 32, 227-255. [CrossRef] [PubMed]

45. Nestle, F.O.; Gilliet, M. Defining upstream elements of psoriasis pathogenesis: An emerging role for interferon alpha. J. Investig. Dermatol. 2005, 125, xiv. [CrossRef]

46. Sa, S.M.; Valdez, P.A.; Wu, J.; Jung, K.; Zhong, F.; Hall, L.; Kasman, I.; Winer, J.; Modrusan, Z.; Danilenko, D.M.; et al. The effects of IL-20 subfamily cytokines on reconstituted human epidermis suggest potential roles in cutaneous innate defense and pathogenic adaptive immunity in psoriasis. J. Immunol. 2007, 178, 2229-2240. [CrossRef]

47. Wilson, N.J.; Boniface, K.; Chan, J.R.; McKenzie, B.S.; Blumenschein, W.M.; Mattson, J.D.; Basham, B.; Smith, K.; Chen, T.; Morel, F.; et al. Development, cytokine profile and function of human interleukin 17-producing helper T cells. Nat. Immunol. 2007, 8, 950-957. [CrossRef]

48. Fuentes-Duculan, J.; Bonifacio, K.M.; Hawkes, J.E.; Kunjravia, N.; Cueto, I.; Li, X.; Gonzalez, J.; Garcet, S.; Krueger, J.G. Autoantigens ADAMTSL5 and LL37 are significantly upregulated in active Psoriasis and localized with keratinocytes, dendritic cells and other leukocytes. Exp. Dermatol. 2017, 26, 1075-1082. [CrossRef]

49. Schuler, G.; Steinman, R.M. Murine epidermal Langerhans cells mature into potent immunostimulatory dendritic cells in vitro. J. Exp. Med. 1985, 161, 526-546. [CrossRef]

50. Doebel, T.; Voisin, B.; Nagao, K. Langerhans Cells-The Macrophage in Dendritic Cell Clothing. Trends Immunol. 2017, 38, 817-828. [CrossRef]

51. Bos, J.D.; Hulsebosch, H.J.; Krieg, S.R.; Bakker, P.M.; Cormane, R.H. Immunocompetent cells in psoriasis. In situ immunophenotyping by monoclonal antibodies. Arch. Dermatol. Res. 1983, 275, 181-189. [CrossRef] [PubMed] 
52. Glitzner, E.; Korosec, A.; Brunner, P.M.; Drobits, B.; Amberg, N.; Schonthaler, H.B.; Kopp, T.; Wagner, E.F.; Stingl, G.; Holcmann, M.; et al. Specific roles for dendritic cell subsets during initiation and progression of psoriasis. EMBO Mol. Med. 2014, 6, 1312-1327. [CrossRef]

53. Lisi, P. Investigation on Langerhans cells in pathological human epidermis. Acta Derm.-Venereol. 1973, 53, 425-428. [PubMed]

54. Baker, B.S.; Swain, A.F.; Griffiths, C.E.; Leonard, J.N.; Fry, L.; Valdimarsson, H. Epidermal T lymphocytes and dendritic cells in chronic plaque psoriasis: The effects of PUVA treatment. Clin. Exp. Immunol. 1985, 61, 526-534.

55. Komine, M.; Karakawa, M.; Takekoshi, T.; Sakurai, N.; Minatani, Y.; Mitsui, H.; Tada, Y.; Saeki, H.; Asahina, A.; Tamaki, K. Early inflammatory changes in the "perilesional skin" of psoriatic plaques: Is there interaction between dendritic cells and keratinocytes? J. Investig. Dermatol. 2007, 127, 1915-1922. [CrossRef]

56. Terhorst, D.; Chelbi, R.; Wohn, C.; Malosse, C.; Tamoutounour, S.; Jorquera, A.; Bajenoff, M.; Dalod, M.; Malissen, B.; Henri, S. Dynamics and Transcriptomics of Skin Dendritic Cells and Macrophages in an Imiquimod-Induced, Biphasic Mouse Model of Psoriasis. J. Immunol. 2015, 195, 4953-4961. [CrossRef] [PubMed]

57. Czernielewski, J.; Juhlin, L.; Shroot, S.; Brun, P. Langerhans' cells in patients with psoriasis: Effect of treatment with PUVA, PUVA bath, etretinate and anthralin. Acta Derm.-Venereol. 1985, 65, 97-101.

58. Gommans, J.M.; van Hezik, S.J.; van Huystee, B.E. Flow cytometric quantification of T6-positive cells in psoriatic epidermis after PUVA and methotrexate therapy. Br. J. Dermatol. 1987, 116, 661-666. [CrossRef]

59. Gunther, C.; Starke, J.; Zimmermann, N.; Schakel, K. Human 6-sulfo LacNAc (slan) dendritic cells are a major population of dermal dendritic cells in steady state and inflammation. Clin. Exp. Dermatol. 2012, 37, 169-176. [CrossRef]

60. Martini, E.; Wiken, M.; Cheuk, S.; Gallais Serezal, I.; Baharom, F.; Stahle, M.; Smed-Sorensen, A.; Eidsmo, L. Dynamic Changes in Resident and Infiltrating Epidermal Dendritic Cells in Active and Resolved Psoriasis. J. Investig. Dermatol. 2017, 137, 865-873. [CrossRef]

61. Cumberbatch, M.; Singh, M.; Dearman, R.J.; Young, H.S.; Kimber, I.; Griffiths, C.E. Impaired Langerhans cell migration in psoriasis. J. Exp. Med. 2006, 203, 953-960. [CrossRef] [PubMed]

62. Eaton, L.H.; Chularojanamontri, L.; Ali, F.R.; Theodorakopoulou, E.; Dearman, R.J.; Kimber, I.; Griffiths, C.E. Guttate psoriasis is associated with an intermediate phenotype of impaired Langerhans cell migration. Br. J. Dermatol. 2014, 171, 409-411. [CrossRef]

63. Eaton, L.H.; Dearman, R.J.; Kimber, I.; Griffiths, C.E.M. Keratinocytes derived from late-onset-psoriasis skin do not impair Langerhans cell migration. Br. J. Dermatol. 2018, 179, 1208-1209. [CrossRef]

64. Nakajima, K.; Kataoka, S.; Sato, K.; Takaishi, M.; Yamamoto, M.; Nakajima, H.; Sano, S. Stat3 activation in epidermal keratinocytes induces Langerhans cell activation to form an essential circuit for psoriasis via IL-23 production. J. Dermatol. Sci. 2019, 93, 82-91. [CrossRef] [PubMed]

65. Zheng, T.; Zhao, W.; Li, H.; Xiao, S.; Hu, R.; Han, M.; Liu, H.; Liu, Y.; Otsu, K.; Liu, X.; et al. p38alpha signaling in Langerhans cells promotes the development of IL-17-producing T cells and psoriasiform skin inflammation. Sci. Signal. 2018, 11, eaao1685. [CrossRef]

66. Ding, W.; Wagner, J.A.; Granstein, R.D. CGRP, PACAP, and VIP modulate Langerhans cell function by inhibiting NF-kappaB activation. J. Investig. Dermatol. 2007, 127, 2357-2367. [CrossRef]

67. Mosser, D.M.; Edwards, J.P. Exploring the full spectrum of macrophage activation. Nat. Rev. Immunol. 2008, 8, 958-969. [CrossRef] [PubMed]

68. Fuentes-Duculan, J.; Suarez-Farinas, M.; Zaba, L.C.; Nograles, K.E.; Pierson, K.C.; Mitsui, H.; Pensabene, C.A.; Kzhyshkowska, J.; Krueger, J.G.; Lowes, M.A. A subpopulation of CD163-positive macrophages is classically activated in psoriasis. J. Investig. Dermatol. 2010, 130, 2412-2422. [CrossRef] [PubMed]

69. Zaba, L.C.; Fuentes-Duculan, J.; Steinman, R.M.; Krueger, J.G.; Lowes, M.A. Normal human dermis contains distinct populations of CD11c+BDCA-1+ dendritic cells and CD163+FXIIIA+ macrophages. J. Clin. Investig. 2007, 117, 2517-2525. [CrossRef] [PubMed]

70. Van der Does, A.M.; Beekhuizen, H.; Ravensbergen, B.; Vos, T.; Ottenhoff, T.H.; van Dissel, J.T.; Drijfhout, J.W.; Hiemstra, P.S.; Nibbering, P.H. LL-37 directs macrophage differentiation toward macrophages with a proinflammatory signature. J. Immunol. 2010, 185, 1442-1449. [CrossRef]

71. Eberle, F.C.; Bruck, J.; Holstein, J.; Hirahara, K.; Ghoreschi, K. Recent advances in understanding psoriasis. F1000Research 2016, 5, 1442-1449. [CrossRef] [PubMed]

72. Reynolds, G.; Vegh, P.; Fletcher, J.; Poyner, E.F.M.; Stephenson, E.; Goh, I.; Botting, R.A.; Huang, N.; Olabi, B.; Dubois, A.; et al. Developmental cell programs are co-opted in inflammatory skin disease. Science 2021, 371, eaba6500. [CrossRef] [PubMed]

73. Mehta, H.; Angsana, J.; Bissonnette, R.; Munoz-Elias, E.J.; Sarfati, M. Inflammatory Skin Disorders: Monocyte-Derived Cells Take Center Stage. Front. Immunol. 2021, 12, 691806. [CrossRef]

74. Kim, J.; Krueger, J.G. The immunopathogenesis of psoriasis. Dermatol. Clin. 2015, 33, 13-23. [CrossRef] [PubMed]

75. Li, N.; Yamasaki, K.; Saito, R.; Fukushi-Takahashi, S.; Shimada-Omori, R.; Asano, M.; Aiba, S. Alarmin function of cathelicidin antimicrobial peptide LL37 through IL-36gamma induction in human epidermal keratinocytes. J. Immunol. 2014, 193, 5140-5148. [CrossRef] [PubMed]

76. Suarez-Farinas, M.; Lowes, M.A.; Zaba, L.C.; Krueger, J.G. Evaluation of the psoriasis transcriptome across different studies by gene set enrichment analysis (GSEA). PLoS ONE 2010, 5, e10247. [CrossRef] 
77. Nograles, K.E.; Zaba, L.C.; Guttman-Yassky, E.; Fuentes-Duculan, J.; Suarez-Farinas, M.; Cardinale, I.; Khatcherian, A.; Gonzalez, J.; Pierson, K.C.; White, T.R.; et al. Th17 cytokines interleukin (IL)-17 and IL-22 modulate distinct inflammatory and keratinocyteresponse pathways. Br. J. Dermatol. 2008, 159, 1092-1102. [CrossRef]

78. Li, H.; Yao, Q.; Mariscal, A.G.; Wu, X.; Hulse, J.; Pedersen, E.; Helin, K.; Waisman, A.; Vinkel, C.; Thomsen, S.F.; et al. Epigenetic control of IL-23 expression in keratinocytes is important for chronic skin inflammation. Nat. Commun. 2018, 9, 1420. [CrossRef]

79. Albanesi, C.; De Pita, O.; Girolomoni, G. Resident skin cells in psoriasis: A special look at the pathogenetic functions of keratinocytes. Clin. Dermatol. 2007, 25, 581-588. [CrossRef]

80. Nordlind, K.; Thorslund, K.; Lonne-Rahm, S.; Mohabbati, S.; Berki, T.; Morales, M.; Azmitia, E.C. Expression of serotonergic receptors in psoriatic skin. Arch. Dermatol. Res. 2006, 298, 99-106. [CrossRef]

81. Scholzen, T.; Armstrong, C.A.; Bunnett, N.W.; Luger, T.A.; Olerud, J.E.; Ansel, J.C. Neuropeptides in the skin: Interactions between the neuroendocrine and the skin immune systems. Exp. Dermatol. 1998, 7, 81-96. [CrossRef] [PubMed]

82. Wang, X.N.; McGovern, N.; Gunawan, M.; Richardson, C.; Windebank, M.; Siah, T.W.; Lim, H.Y.; Fink, K.; Yao Li, J.L.; Ng, L.G.; et al. A three-dimensional atlas of human dermal leukocytes, lymphatics, and blood vessels. J. Investig. Dermatol. 2014, 134, 965-974. [CrossRef] [PubMed]

83. Harvima, I.T.; Nilsson, G.; Suttle, M.M.; Naukkarinen, A. Is there a role for mast cells in psoriasis? Arch. Dermatol. Res. 2008, 300, 461-478. [CrossRef] [PubMed]

84. Church, M.K. Reassessment of mast cell stabilizers in the treatment of respiratory disease. Ann. Allergy 1989, 62, $215-221$. [PubMed]

85. Theoharides, T.C.; Zhang, B.; Kempuraj, D.; Tagen, M.; Vasiadi, M.; Angelidou, A.; Alysandratos, K.D.; Kalogeromitros, D.; Asadi, S.; Stavrianeas, N.; et al. IL-33 augments substance P-induced VEGF secretion from human mast cells and is increased in psoriatic skin. Proc. Natl. Acad. Sci. USA 2010, 107, 4448-4453. [CrossRef]

86. Lin, A.M.; Rubin, C.J.; Khandpur, R.; Wang, J.Y.; Riblett, M.; Yalavarthi, S.; Villanueva, E.C.; Shah, P.; Kaplan, M.J.; Bruce, A.T. Mast cells and neutrophils release IL-17 through extracellular trap formation in psoriasis. J. Immunol. 2011, 187, 490-500. [CrossRef]

87. Gaudenzio, N.; Laurent, C.; Valitutti, S.; Espinosa, E. Human mast cells drive memory CD4+ T cells toward an inflammatory IL-22+ phenotype. J. Allergy Clin. Immunol. 2013, 131, 1400-1407. [CrossRef]

88. Zhang, Y.; Shi, Y.; Lin, J.; Li, X.; Yang, B.; Zhou, J. Immune Cell Infiltration Analysis Demonstrates Excessive Mast Cell Activation in Psoriasis. Front. Immunol. 2021, 12, 773280. [CrossRef]

89. Dimitriadou, V.; Mecheri, S.; Koutsilieris, M.; Fraser, W.; Al-Daccak, R.; Mourad, W. Expression of functional major histocompatibility complex class II molecules on HMC-1 human mast cells. J. Leukoc. Biol. 1998, 64, 791-799. [CrossRef]

90. Lotfi-Emran, S.; Ward, B.R.; Le, Q.T.; Pozez, A.L.; Manjili, M.H.; Woodfolk, J.A.; Schwartz, L.B. Human mast cells present antigen to autologous CD4(+) T cells. J. Allergy Clin. Immunol. 2018, 141, 311-321. [CrossRef]

91. Babolewska, E.; Brzezinska-Blaszczyk, E. Human-derived cathelicidin LL-37 directly activates mast cells to proinflammatory mediator synthesis and migratory response. Cell. Immunol. 2015, 293, 67-73. [CrossRef] [PubMed]

92. Christophers, E.; van de Kerkhof, P.C.M. Severity, heterogeneity and systemic inflammation in psoriasis. J. Eur. Acad. Dermatol. Venereol. JEADV 2019, 33, 643-647. [CrossRef] [PubMed] 